\title{
Insulin-like growth factor-1, growth hormone, and daily cycling estrogen are associated with mammographic density in premenopausal women
}

\section{Citation}

Frydenberg, Hanne, Vidar G. Flote, Anita Iversen, Sissi E. Finstad, Anne-Sofie Furberg, Peter A. Torjesen, Tom Wilsgaard, et al. 2014. "Insulin-Like Growth Factor-1, Growth Hormone, and Daily Cycling Estrogen Are Associated with Mammographic Density in Premenopausal Women." Cancer Causes \& Control 25 (7) (May 7): 891-903. doi:10.1007/s10552-014-0389-z.

\section{Published Version}

doi:10.1007/s10552-014-0389-z

\section{Permanent link}

http://nrs.harvard.edu/urn-3:HUL.InstRepos:25201562

\section{Terms of Use}

This article was downloaded from Harvard University's DASH repository, and is made available under the terms and conditions applicable to Open Access Policy Articles, as set forth at http:// nrs.harvard.edu/urn-3:HUL.InstRepos:dash.current.terms-of-use\#OAP

\section{Share Your Story}

The Harvard community has made this article openly available.

Please share how this access benefits you. Submit a story.

Accessibility 


\section{Insulin-like growth factor-1, growth hormone and daily cycling estrogen are associated with mammographic density in premenopausal women.}

Hanne Frydenberg, ${ }^{1}$ Vidar G Flote, ${ }^{1}$ Anita Iversen, ${ }^{2}$ Sissi E Finstad, ${ }^{1}$ Anne-Sofie Furberg, ${ }^{3}$ Peter A Torjesen, ${ }^{4}$ Tom Wilsgaard, ${ }^{3}$ Ellen Schlichting, ${ }^{1}$ Peter T Ellison, ${ }^{5}$ Giske Ursin ${ }^{6}$ and Inger Thune ${ }^{1,3}$

\footnotetext{
${ }^{1}$ Department of Oncology, Oslo University Hospital, Ullevål, Norway

${ }^{2}$ Faculty of Health Sciences, UiT, The Arctic University of Norway. 9037 Tromsø, Norway

${ }^{3}$ Department of Community Medicine, Faculty of Health Sciences, UiT, The Arctic University of Norway. Tromsø, Norway

${ }^{4}$ Hormone Laboratory, Oslo University Hospital, Aker, Norway

${ }^{5}$ Department of Human Evolutionary Biology, Harvard University, Cambridge, MA, USA,

${ }^{6}$ The Norwegian Cancer Registry, Oslo, Norway.
}

Running title: IGF-1, GH, estrogen and mammographic density

Keywords: mammographic density; IGF-1; GH; 17ß-estradiol; breast cancer.

Address for correspondence:

MD Hanne Frydenberg

Dep. of Oncology, Oslo University Hospital HF, Ullevål

$\mathrm{N}-0424$ Oslo Norway

Cell phone: 0047 92233226, e-mail: hanne.frydenberg@medisin.uio.no

Word count: Abstract 250, Manuscript 4419.

Number of tables/figures: 4, supplementary tables: 2

\section{Abstract}


Background: Mammographic density represents epithelial and stromal proliferation, while Insulin-like growth factor (IGF)-1, IGF-binding protein (IGFBP)-3, growth hormone (GH) and estrogen, may influence cellular proliferation. However, whether these growth factors independently, or in combination with estrogen, influence mammographic density in premenopausal women remains unclear.

Material and methods: Growth factors were assessed in 202 ovulating premenopausal women participating in the Energy Balance and Breast cancer Aspects (EBBA)-I study. Estrogen was assessed in serum, and daily in saliva, throughout a menstrual cycle. Computerassisted mammographic density (Madena) was obtained from digitized mammograms (days 7-12 of the menstrual cycle). Associations between growth factors, estrogen and percent mammographic density, were studied in regression models.

Results: Women with a mean age of 30.7 years had a mean percent mammographic density of $29.8 \%$. Among women in the strata (above median split) of IGF-1 ( $>25 \mathrm{nmol} / \mathrm{l}$ ) or GH $(>0.80 \mathrm{mlU} / \mathrm{l})$, we observed that an increase in salivary $17 \beta-$-estradiol, was associated with a higher odds for having higher percent mammographic density $(>28.5 \%)$. The odds ratios (ORs) per standard deviation increase of $17 \beta$-estradiol, were 1.81 ( $95 \%$ confidence interval [CI] 1.08-3.03) in the high IGF-1 stratum, and 2.08 (95\% CI 1.10-3.94) in the high GH stratum. Furthermore, women in this strata of growth factors (above median) who had an overall average $17 \beta$-estradiol above median (>16.8 pmol/1), had higher ORs for having higher percent mammographic density (>28.5\%): IGF-1 4.13 (95\% CI 1.33-12.83), and GH 4.17 (95\% CI 1.41-12.28).

Conclusion: Growth factors, in combination with cycling estrogen, were associated with percent mammographic density, of potential clinical relevance.

\section{Introduction}


Mammographic density represents epithelial and stromal proliferation, and is a strong biomarker for breast cancer development [1]. Ovarian steroid hormones and growth factors, on the other hand, increase cellular proliferation in the breast, which may be reflected through mammographic density. Furthermore, the growth hormone (GH)-insulin-like growth factor-1 (IGF-1) signaling pathway, has been associated with breast cancer [2,3], and IGF-1 is suggested to influence cellular proliferation and inhibit apoptosis through the activation of PI3/Akt pathway, in both normal breast cells and breast cancer cell lines [4,5]. The level of IGF-1 is regulated by GH, and modulated by insulin-like growth factor-binding protein-3 (IGFBP-3). However, whether IGF-1, IGFBP-3 and GH, independently or in combination with ovarian steroid hormones, influence mammographic density among premenopausal women, remains unclear [6,7].

Mammographic density may be described by percent and absolute density. While percent mammographic density represents the fibroglandular tissue and fat tissue, absolute mammographic density represents the dense area. Mammographic density has been reported to vary during the menstrual cycle $[8,9]$, and breast cancer risk factors, including the use of exogenous hormones, have been studied mostly in relation to, and associated with, percent mammographic density [10,11] and breast cancer development [12,13]. Recently, endogenous sex hormone levels and percent mammographic density were associated with breast cancer risk, both independently and in combination [14]. Interestingly, it has been hypothesized that a crosstalk operates between estrogen and the GH-IGF-1 signalling pathways in cells [15-18]. Thus, it is interesting to examine whether the variation in the GH-IGF axis in combination with circulating concentrations of estrogen is associated with mammographic density, described by both percent and absolute density in premenopausal women.

Previously, in the Norwegian Energy Balance and Breast cancer Aspects (EBBA)-I study, we have observed a positive association between daily circulating ovarian sex hormones and mammographic density, using a modified Wolfe classification [19]. In addition, 17 $\beta$-estradiol profiles were associated with traditional breast cancer risk factors, such as age at menarche [19,20], insulin, adult height and metabolic profile in adulthood $[21,19,22]$. These associations also point to the need for further studies of estrogen in combination with the GH-IGF signalling pathway and mammographic density.

Thus, the purpose of this study is to examine whether IGF-1, IGFBP-3 and GH, in combination with circulating concentrations of daily $17 \beta$-estradiol, are associated with mammographic density in premenopausal women. A unique aspect of the current study is the measurement of estrogen in both serum and daily in saliva. The daily salivary $17 \beta$-estradiol 
measured throughout an entire menstrual cycle represents biologically free active estrogen [23]. To facilitate comparisons with other studies and factors affecting various types of breast density, both percent and absolute density have been included.

\section{Materials and methods:}

\section{Participants and study design}

The Norwegian EBBA-I study was conducted in 2000-2002 in Tromsø. It included 204 healthy women aged 25-35 years, with regular menstrual cycles (length 22-38 days) [19,22]. The women did not use any daily medication, or steroid contraceptives, in the 6 months prior to recruitment, they were not pregnant or lactating, and had no gynaecological or chronic disorders (e.g. diabetes, hypothyroidism) [19]. Participants' characteristics, including reproductive and lifestyle factors, were collected by a trained nurse using questionnaires and interviews at the time of recruitment. Recall and memory-probing aids, including a lifetime calendar, were used to date specific life events. Two women were excluded due to missing mammographic data, resulting in 202 participants in the present study.

\section{Clinical examination}

All participants underwent clinical examinations at the Clinical Research Centre, University Hospital of North Norway, Tromsø. They attended three scheduled visits during their menstrual cycle, after onset of the menstrual bleeding (first visit days 1-5, second visit days 712 and third visit days 21-25). Anthropometric measurements were conducted with participants wearing light clothing and no footwear. Height was measured to the nearest 0.5 $\mathrm{cm}$, and weight to the nearest $0.1 \mathrm{~kg}$ on a regularly calibrated electronic scale. Body mass index (BMI) was calculated as weight in kilograms per height in square meter $\left(\mathrm{kg} / \mathrm{m}^{2}\right)$. Waist circumference (WC) was measured to the nearest $0.5 \mathrm{~cm}, 2.5 \mathrm{~cm}$ above the umbilicus. A whole body scan was obtained at the second visit for the estimation of the total percentage of fat tissue, using dual-energy X-ray absorptiometry (DEXA; DPLX-L 2288, Lunar Radiation Corporation, Madison, WI, USA). The percentage of fat tissue was estimated using Lunar software. 
Fasting serum samples were drawn in the morning from the antecubital vein at the three scheduled visits. Serum glucose was measured enzymatically using the hexokinase method at the Department of Clinical Chemistry, University Hospital of North Norway, Tromsø.

\section{Collection of hormones - IGF-1, IGFBP-3, GH and estrogen}

Fasting morning blood samples of insulin, IGF-1 and IGFBP-3, were obtained at the first scheduled visit, and fasting serum concentrations of GH was obtained at the second scheduled visit. Insulin, IGF-1 and IGFBP-3, were measured in serum stored at $-70^{\circ} \mathrm{C}$ for up to 3 years until analysis took place at the Hormone Laboratory, University Hospital of Oslo, Aker. Serum insulin was measured by radioimmunoassay (RIA) using kits from Linco Research Inc (St.Charles, MO, USA). IGF-1 and IGFBP-3, measured as glycosylated, were determined by ILMA, Immulite 2000 (Diagnostic Products Co, Los Angeles, CA, USA). GH was measured in serum, stored at $-70^{\circ} \mathrm{C}$ for up to 10 years until analysis, which took place at the Hormone Laboratory, University Hospital of Oslo, Aker. DELFIA kits from PerkinElmer Life Sciences (Wallac Oy, Turku, Finland) were used for the GH analysis. The coefficients of variation (CVs) derived from the laboratories were as follows: 7-10\% for IGF-1 and 6\% for IGFBP-3. For GH the average intra-assay variability was $1.9 \%$, and the inter-assay variability ranged from $5.5 \%$ for low pools $(0.29 \mathrm{mlU} / \mathrm{l})$ to $2.5 \%$ for high pools $(38.7 \mathrm{mlU} / \mathrm{l})$.

Fasting serum $17 \beta$-estradiol concentrations were measured consecutively, by direct immunometric assay (Immuno-1, Bayer Diagnostics, Norway), at the three scheduled visits during the menstrual cycle.

The participants self-collected daily morning saliva samples, into plastic tubes pretreated with sodium azide, starting on the first day of bleeding, for one menstrual cycle, according to collection protocols previously established at the Reproductive Ecology Laboratory, Harvard University, USA [19,24,25]. Levels of salivary 17ß-estradiol concentrations, were measured in daily saliva samples from 20 days (reverse cycle days -5 to -24; with the last day of the menstrual cycle designated -1) using ${ }^{125}$ I-labelled RIA kits (\#39100, Diagnostic Systems Laboratories, Webster, TX, USA), along with published modifications of the manufacturer's protocols [19]. Overall average 17 $\beta$-estradiol concentrations, was calculated using daily levels of $17 \beta$ salivary- estradiol. All samples were run in duplicate, and from a single participant, all samples were run together in the same assay with women randomly assigned to assay batches. The CVs were calculated based on the high and low value pools included in each assay. 
Salivary assays have higher variability than serum assays, because their measuring levels are one to two orders of magnitude lower in concentration. In the present study measurements of $17 \beta$-estradiol at the start and end of the menstrual cycles had higher CV's. The sensitivity of the $17 \beta$-estradiol assay (the lowest $17 \beta$-estradiol concentration distinguishable from 0 at a 95\% level) was 4 pmol/l. Average intra-assay variability was 9\%, and inter-assay variability ranged from $23 \%$ for low pools, to $13 \%$ for high pools. Therefore, we included $17 \beta$-estradiol measurements from aligned cycle days -7 to +6 in the linear models. All cycles of the participants were aligned based on the identification of the midcycle drop in salivary $17 \beta$-estradiol concentration (aligned cycle day 0 ). The drop provides an estimate of the day of ovulation [26]. A drop in 17 $\beta$-estradiol could not be identified for 14 women, hence their cycles could not be aligned and they were not included in the statistical analysis. Overall salivary $17 \beta$-estradiol concentrations were calculated for all 202 women, whereas hormonal indices (e.g. follicular, mid-menstrual and luteal phases) were calculated only for the women with aligned cycles $(n=188)$.

\section{Mammograms and mammographic density}

Bilateral two-view mammograms were obtained from all women, during the second scheduled visit (between cycle days 7 and 12 after onset of bleeding), at the Centre of Breast Imaging, University Hospital of North Norway, Tromsø, using a standard protocol [19,27].

The left craniocaudal mammograms were digitized and imported into a computerized mammographic density assessment program (Madena), developed at the University of Southern California School of Medicine (Los Angeles, CA, USA) [28,29]. The density measurements were conducted by a trained reader (G. Ursin). These were done as follows: First a region of interest (ROI) [13] that included the entire breast, but excluded light artifacts such as the pectoralis muscle, prominent veins and fibrous strands was outlined. The mammogram reader then used a tinting tool to tint pixels considered to represent areas of mammographic density. The Madena software estimated the number of tinted pixels within the ROI. Absolute mammographic density represents the tinted pixels within the ROI, and percent mammographic density is the ratio of absolute mammographic density to the total breast area multiplied by 100 . The mammograms were read in four batches, with an equal number of mammograms in each batch. A duplicate reading of 26 randomly selected mammograms from 2 of the batches showed a Pearson's correlation coefficient of 0.97 . The reader was blinded to any characteristics of the study population. 


\section{Statistical analysis}

To study the associations between characteristics of the women and percent and absolute mammographic density, we used Students t-test. Linear mixed models for repeated measures were used to investigate the association between fasting high or low serum concentrations of IGF-1, IGFBP-3 and GH, in combination with salivary 17 $\beta$-estradiol concentrations throughout an entire menstrual cycle, and the study outcomes; percent and absolute mammographic density. This was done to take into account a potential combined effect of growth hormones and cycling estrogen throughout the menstrual cycle among premenopausal women in relation to mammographic density.

Based on plausible biological mechanisms, and previous findings suggesting a threshold effect between growth factors and breast cancer development [2], we stratified the regression analysis by median split of IGF-1 (25 nmol/l) and GH (0.80 mlU/l). Multivariable logistic and linear regression models were used to assess the associations between GH, IGF-1, estrogens and mammographic density. In the logistic regression models median split of percent and absolute mammographic density were used as dependent variables, $>28.5 \%$ [yes/no], $>32.4 \mathrm{~cm}^{2}$ [yes/no] and the GH-IGF-1 axis, and measures of $17 \beta$-estradiol (serum, salivary; overall, mid-menstrual, follicular, luteal and area under curve) throughout a menstrual cycle as independent variables. The $17 \beta$-estradiol levels were included as categorical variables (median split) and as continuous variables with one standard deviation (SD) increase. In the linear regression models, both percent and absolute mammographic density were used as dependent variables, and the GH-IGF-1 axis, and measures of $17 \beta-$ estradiol throughout a menstrual cycle as independent variables. The $17 \beta$-estradiol levels were included as continuous variables with one SD increase.

The variables, including the breast density measures, were approximately normally distributed, thus no transformations were needed. Moreover, there were no observations of any outliers that could be driving the associations. Based on previously established observations, including results from the same study population [19] and suggested biological mechanisms, which may influence breast density, growth factors or levels of estradiol, several models were tested, including a variety of potentially confounding variables. We tested whether adjustments for potentially confounding factors such as age (continuous in years), BMI (continuous in $\mathrm{kg} / \mathrm{m}^{2}$ ), age at menarche (continuous in years), number of children (continuous in numbers), previous oral contraceptive use (categorical, yes/no), alcohol intake (continuous in units/week), smoking habits (categorical, yes/no), energy intake (continuous in $\mathrm{kJ} /$ day) and leisure time activity (continuous in metabolic equivalents [METs] hours/week) 
influenced our estimates. Previous oral contraceptive use, age at menarche, alcohol intake, smoking habits, energy intake and leisure time activity were all tested as potential confounders, but as these factors did not influence our results they were not included in the final model. The adjustment factors in the final model were age, BMI and number of children. IGF-1 and IGFBP-3 were adjusted for each other when appropriate. The area under the curve (AUC) for estradiol was calculated for each participant with an aligned cycle (days -10 to +9 ) using the trapezium rule [30]. The results were considered statistically significant when twosided $p<0.05$. The analyses were conducted with SPSS version 21.0.

\section{Ethical considerations}

All the participating women signed an informed consent form. The Regional Committee for Medical Research Ethics and the Norwegian Data Inspectorate approved the study.

\section{Results}

Selected general characteristics of the study participants are provided in Table 1. Among women with a mean age of 30.7 years, a mean salivary $17 \beta$-estradiol concentration of 17.9 pmol/1, a mean percent mammographic density of $29.8 \%$ (median $28.5 \%$ ), and a mean absolute mammographic density of $34.7 \mathrm{~cm}^{2}$ (median $32.4 \mathrm{~cm}^{2}$ ) was observed (Results not presented in table). Age, parity and body composition (BMI, waist circumference and total tissue fat) were inversely associated with both percent mammographic density $(>28.5 \%)$ and absolute mammographic density $\left(>32.4 \mathrm{~cm}^{2}\right)$. We observed IGF-1, IGFBP-3 and growth hormone independently, and in association with percent and absolute mammographic density, and no trends were observed (Table 1).

We examined women with high and low levels of growth factors (median split of IGF1, IGFBP-3 and GH) in combination with mean salivary $17 \beta$-estradiol concentrations, throughout the mid-menstrual phase in relation to percent mammographic density. When we compared women with high IGF-1 (>25 nmol/l) and lower percent mammographic density $(\leq 28.5 \%)$, with women with high IGF-1 $(>25 \mathrm{nmol} / \mathrm{l})$ and higher percent mammographic density $(>28.5 \%)$; we observed a $38.3 \%$ difference in overall average $17 \beta$-estradiol $(p=$ 0.023). Similarly, women with either high IGFBP-3 ( $>100 \mathrm{nmol} / \mathrm{l})$ or high GH $(>0.80 \mathrm{mlU} / \mathrm{l})$ and lower percent mammographic density $(\leq 28.5 \%)$, compared with women with higher percent mammographic density $(>28.5 \%)$, we observed a difference in overall average $17 \beta$ estradiol of $34.1 \%(p=0.024)$ and $34.2 \%(p=0.013)$, respectively. Among women with low IGF-1 $(\leq 25 \mathrm{nmol} / \mathrm{l})$, low IGFBP-3 $(\leq 100 \mathrm{nmol} / \mathrm{l})$ or low GH $(\leq 0.80 \mathrm{mlU} / \mathrm{l})$, we observed no 
difference in mean salivary $17 \beta$-estradiol concentrations for those with higher or lower percent mammographic density (Figure 1). The IGF-1:IGFBP-3 ratio showed the same pattern as described for IGF-1 and IGFBP-3 alone (data not shown).

When we stratified by median split of IGF-1, IGFBP-3 and GH, and examined the mean salivary $17 \beta$-estradiol concentrations throughout the mid-menstrual phase in relation to absolute mammographic density, $\left(\leq 32.4 \mathrm{~cm}^{2},>32.4 \mathrm{~cm}^{2}\right)$ no differences were observed (results not shown in table).

In stratified analysis of growth factors (median split), the association between 17ßestradiol (both as a continuous and binary [median split] variable) and percent mammographic density was further evaluated in multivariable analysis (adjusted by age, BMI and number of children, and IGFBP-3 or IGF-1 when appropriate). In women with high IGF-1 ( $>25 \mathrm{nmol} / \mathrm{l})$ or high GH ( $>0.80 \mathrm{mlU} / \mathrm{l})$, a one SD increase in overall average salivary $17 \beta$-estradiol was associated with a 1.81 (95\% confidence interval [CI] 1.08-3.03) and 2.08 (95\% CI 1.10-3.94) times higher odds for having higher percent mammographic density $(>28.5 \%)$, respectively. Similarly, in women with high levels of IGF-1 or GH, overall average 17 $\beta$-estradiol above versus below median (16.8 pmol/1), was associated with a 4.13 (95\% CI 1.33-12.83) and 4.17 (95\% CI 1.41-12.28) times higher odds for having higher percent mammographic density $(>28.5 \%)$, respectively. In women with IGFBP-3 (>100 nmol/l), the corresponding odds was 3.62 (95\% CI 1.15-11.38) (results not shown in table). When we subdivided the menstrual cycle into mid-menstrual, follicular and luteal phases, we observed adjusted ORs comparable to the results listed above for overall salivary $17 \beta$-estradiol. In contrast, serum estrogen was not associated with percent mammographic density (Tables 2 and 3). The current study did not reveal any association between IGF-1, IGFBP-3 and GH in combination with 17 $\beta$ estradiol and absolute mammographic density (Results not shown in table).

Linear regression was also performed with percent and absolute mammographic density as continuous variables. There were no associations between high IGF-1, estrogens and mammographic density in the linear regression models. However, among women with high $\mathrm{GH}(>0.80 \mathrm{mlU} / \mathrm{l})$, a one SD increase in overall average and follicular phase salivary $17 \beta$-estradiol was positively associated with percent mammographic density. Thus, no associations were found when we used absolute mammographic density as the dependent variable (Supplementary table 1 and 2). The association between percent mammographic density and different categories of 17 $\beta$-estradiol and IGF-1 (low 17 $\beta$-estradiol -low IGF-1, low $17 \beta$-estradiol -high IGF-1, high $17 \beta$-estradiol -low IGF-1, and high 17 $\beta$-estradiol -high IGF-1) were also tested. The category with both high $17 \beta$-estradiol and high IGF-1 showed an 
increased OR for having high percent mammographic density; however the other categories were not associated with having high percent mammographic density (results not shown in table).

To test for interaction between the 17 $\beta$-estradiol variables, and IGF-1, IGFBP-3 or $\mathrm{GH}$, all variables were first dichotomized and then entered into logistic regression models with interaction terms. In addition, we tested for interaction between $17 \beta$-estradiol as a continuous variable, and growth factors as dichotomized variables. We observed statistically significant interactions between the IGF-1 and AUC of salivary $17 \beta$-estradiol, and midmenstrual salivary $17 \beta$-estradiol, and between GH and overall salivary $17 \beta$-estradiol (Tables 2 and 3$)$.

\section{Discussion}

In the present study, we observed that premenopausal women with higher levels of growth factors, in combination with daily salivary $17 \beta$-estradiol, have higher odds for having higher percent mammographic density, independent of age, BMI and number of children. In women with high IGF-1 ( $>25 \mathrm{nmol} / \mathrm{l})$, or high $\mathrm{GH}(>0.80 \mathrm{mlU} / \mathrm{l})$, there was a positive relationship between $17 \beta$-estradiol and percent mammographic density, with up to a doubling in odds by one SD increase of salivary $17 \beta$-estradiol. These findings were further strengthened in women with high IGF-1 or high GH, combined with levels above median of daily cycling $17 \beta-$ estradiol $(>16.8 \mathrm{pmol} / \mathrm{l})$, as these women had a three- to four times higher odds for having higher percent mammographic density $(>28.5 \%)$.

The present results extend our own [19], and previous reports [31-33], as we observed a positive association between growth factors in combination with estrogen and mammographic density, not only an association between estrogen alone and mammographic density. Interestingly, a crosstalk between IGF-1 and estrogen in breast cancer development has been hypothesized [15-18]. Recently, GH action was studied in a panel of estrogen receptor-positive breast cancer cell lines, and GH significantly enhanced 17ß-estradiolstimulated proliferation in these cells. Interestingly, the combination of GH and 17 $\beta$-estradiol overcame inhibition of IGF-I receptor activity to restore proliferation [18]. These observations support a potential joint effect of growth factors and estrogen on breast cancer development. Our observations are also partly supported by others [33]. Among premenopausal women, positive associations were observed both between IGF-1 and between estrogen and percent mammographic density. However, estrogen was assessed on six consecutive days in relation 
to ovulation and one day in the luteal phase in urine, but interestingly when they adjusted for BMI, the association was attenuated [33].

Interestingly, we did not observe any clear association between any of the growth factors alone and percent mammographic density, which is consistent with other studies. Recently, no association between GH, IGF-1 and percent and absolute mammographic density was observed for either premenopausal or postmenopausal women [6], which correspond to the results ofothers [34-36]. Furthermore, our observation of an association between IGF-1 and percent mammographic density, mainly seen among women with higher levels of IGF-1 suggest a threshold effect. This association is indirectly supported by Hankinson and coauthors as they observed an increased breast cancer risk among premenopausal women in the upper tertile of IGF-1 only [2]. Whether a linear association or a threshold effect exists between growth factors and percent mammographic density may be questioned, but our findings of no linear association with an interaction between growth factors, in combinations with continuous estrogen and percent mammographic density lends support to a threshold effect between growth factors and mammographic density. Other findings may also indirectly support a threshold effect only among women with high percent mammographic density. In a cohort study from the Netherlands, women aged 35 and older with percent mammographic density above $25 \%$, had a 2 times increased odds ratio for breast cancer development [37]. Moreover, recently percent mammographic density above $25 \%$ was associated with later increased postmenopausal breast cancer risk [1]. These results partly support a threshold effect, and support our cut off of $28.5 \%$ for percent mammographic density as an appropriate cut off level.

To note, our observed association between growth factors in combination with estrogen and percent mammographic density, were not observed with absolute mammographic density. These findings can partly be explained by the fact that absolute mammographic density reflect the dense breast tissue, while percent mammographic density reflects fibroglandular and fat tissue [38]. Moreover, such an association between growth factors and percent mammographic density has been suggested to reflect cumulative exposure of hormones and growth factors in breast stroma and epithelium to stimulate cell division $[39,38]$. Thus, estrogen and growth factors may influence not only the dense area, but the stroma and the surrounding adipose tissue. Importantly, others have observed that fibroglandular and fat tissue may have independent effects on breast cancer development [40].

Altogether, even if plausible mechanisms have been suggested, and has been supported by experimental studies [41], less is known about the association of the GH-IGF 
signaling pathway, estrogen and mammographic density. Recently, estrogen and IGF-1 have been observed to have synergistic effects on the growth of breast cancer cells [41]. Moreover, GH regulates the production of IGF-1, and around $99 \%$ of circulating IGF-1 is bound to IGFBP-3. IGF binds to the tyrosine kinase receptor, which induces an intracellular signalling cascade. IGF-1 receptor activation primarily leads to proliferation and differentiation [42]. The GH, IGF-1 and IGFBP-3 levels are age dependent and decrease after puberty. Some studies have examined the GH-IGF signaling pathway in association with mammographic density, for both premenopausal and postmenopausal women, but the results are indifferent $[43,44,34]$. For postmenopausal women, however, the growth factor levels, estrogen levels and mammographic densities are lower than that for premenopausal women. This may explain in part, why no associations between these growth factors and mammographic density have been observed for postmenopausal women [34,35,43]. Thus, the higher levels of cyclic estrogen and serum level of growth factors may be more likely to capture the aetiologically relevant exposure period, and may explain in part why the associations are more pronounced among premenopausal women [45]. Furthermore, estrogen and mammographic density varies throughout the menstrual cycle and this could partly explain why some studies that measure estrogen in serum did not show associations with mammographic density [31,46]. Variations in the populations may also be explained by the fact that variations in IGF-1 levels have been observed in relation to single-nucleotide polymorphisms as well as lifestyle factors (such as age, nutrition, hepatic function) [47].

Recently, both an independent and a combined effect of endogenous sex hormone and percent mammographic density were observed on breast cancer risk [14]. Postmenopausal women in the highest tertile of estradiol and with the highest percent mammographic density $(>24.0 \%)$ had an increased breast cancer risk [14]. These observations support that, including circulating endogenous estrogen, may add additional information about the complexity using mammographic density as a biomarker for breast cancer development.

Thus, our findings of an association between growth factors, estrogen and percent mammographic density with a threshold effect are supported by plausible biological mechanisms, and suggested as a crosstalk in cells between the signalling pathways for estrogens and IGF-1[15,16]. Importantly, GH and IGF-1 signalling, together with estrogens, is essential for the development of the mammary gland, particularly the terminal end-buds. It has also been found that during lactation, IGF-1 plays an important role in the maintenance of the adult mammary gland [48-50]. Furthermore, percent mammographic density refers to the structure of the adipose, epithelial and connective tissue in the breast [51]. Thus, the growth 
factors and estrogens in combination, are key factors in proliferation of breast cells and are potential drivers for breast cancer development [41].

In the present study, we observed a positive association between IGFBP-3 and percent mammographic density, which is in contrast to others [3]. However, the association between IGFBP-3 and breast cancer risk may differ according to whether IGFBP-3 is measured as intact, fragmented or total [52]. In our study, serum IGF-1 and IGFBP-3 are measured once in serum, but have long half-lives and little daily variations. This seems to be adequate for measuring the long-term levels of these peptides [53]. However, GH is normally secreted episodically with 7-10 peaks per day, but importantly with a more constant fasting morning level, as is the case for many other cycling biological markers and the half-life in serum is shorter than that for IGF-1. To minimize these variations, GH was assessed in fasting morning samples, as is the case for all other growth factors. However, caution should be exerted when interpreting the results.

The current study benefited from several unique features, such as salivary measurements of concentrations of unbound 17 $\beta$-estradiol collected daily across an entire menstrual cycle [23,54], following strict procedures [19] and validated methods [26]. Among ovulating premenopausal women, the estrogen levels vary considerably throughout the menstrual cycle, and by using daily salivary samples, we were able to measure the free biologically active form of estrogen, which is considered to be the ideal measure among ovulating premenopausal women $[23,26]$. Thus, we were able to capture the continuous estrogen exposure of the women. Moreover, standardized repeated hormone levels in serum were also included.

Furthermore, mammograms were taken during a narrow time frame in the late follicular phase (days 7-12), thereby avoiding the bias of variation in mammographic density during the menstrual cycle [55]. The validated computer-assisted method has been observed to quantify mammographic density, and shown to give a superior prediction of breast cancer risk compared with qualitative methods [28]. All mammograms were read by one experienced blinded reader, and the assessed mammographic density was negatively associated with age, BMI and number of children [56,57]. Thus, we have adjusted for these confounders in the multiple analyses. The study population was homogenous with healthy women aged 25-35 years from the same cultural background. However, the small sample size of the current study and small number of earlier reports underlines the need for further studies.

In conclusion, based on the biological mechanisms suggested and previous reports, the present findings are unique in character, supporting that IGF-1, IGFBP-3 and GH, in 
combination with cycling bioactive estrogen, may be associated with percent mammographic density in premenopausal women. This combination of biomarkers may also be important in clinical settings. However, our results are based on a relatively small sample size and should be interpreted with caution. Hence, there is a need for replication in larger studies.

\section{Acknowledgements}

We acknowledge each woman that participated in the EBBA-I study and give special thanks to Gunn Kristin Knudsen, Heidi Jakobsen, Anna-Kirsti Kvitnes and Sissel Andersen for their professional assistance. We would also like to thank the Clinical Research Department, University Hospital of North Norway, Tromsø, for their skilled and always professional setting.

\section{Financial support}

This work was supported by the Norwegian Research Council (213997/H10), Foundation for the Norwegian Health and Rehabilitation Organization (59010-2000, 59010-2001, 590102002) and Norwegian Cancer Society (05087, TP 49 258).

Disclose any potential conflicts of interest: None 


\section{Reference list}

1. Yaghjyan L, Colditz GA, Rosner B, Tamimi RM (2013) Mammographic breast density and subsequent risk of breast cancer in postmenopausal women according to the time since the mammogram. Cancer epidemiology, biomarkers \& prevention : a publication of the American Association for Cancer Research, cosponsored by the American Society of Preventive Oncology 22 (6):1110-1117. doi:10.1158/1055-9965.epi-13-0169

2. Hankinson SE, Willett WC, Colditz GA, Hunter DJ, Michaud DS, Deroo B, Rosner B, Speizer FE, Pollak M (1998) Circulating concentrations of insulin-like growth factor-I and risk of breast cancer. Lancet 351 (9113):1393-1396. doi:10.1016/s0140-6736(97)10384-1

3. Diorio C, Pollak M, Byrne C, Masse B, Hebert-Croteau N, Yaffe M, Cote G, Berube S, Morin C, Brisson J (2005) Insulin-like growth factor-I, IGF-binding protein-3, and mammographic breast density. Cancer epidemiology, biomarkers \& prevention : a publication of the American Association for Cancer Research, cosponsored by the American Society of Preventive Oncology 14 (5):1065-1073. doi:10.1158/1055-9965.epi-04-0706

4. Pollak M (2012) The insulin and insulin-like growth factor receptor family in neoplasia: an update. Nature reviews Cancer 12 (3):159-169. doi:10.1038/nrc3215

5. Memmott RM, Dennis PA (2009) Akt-dependent and -independent mechanisms of mTOR regulation in cancer. Cellular signalling 21 (5):656-664. doi:10.1016/j.cellsig.2009.01.004 6. Rice MS, Tworoger SS, Rosner BA, Pollak MN, Hankinson SE, Tamimi RM (2012) Insulin-like growth factor-1, insulin-like growth factor-binding protein-3, growth hormone, and mammographic density in the Nurses' Health Studies. Breast cancer research and treatment 136 (3):805-812. doi:10.1007/s10549-012-2303-2

7. Izzo L, Meggiorini ML, Nofroni I, Pala A, De Felice C, Meloni P, Simari T, Izzo S, Pugliese F, Impara L, Merlini G, Di Cello P, Cipolla V, Forcione AR, Paliotta A, Domenici L, Bolognese A (2012) Insulin-like growth factor-I (IGF-1), IGF-binding protein-3 (IGFBP-3) and mammographic features. Il Giornale di chirurgia 33 (5):153-162

8. Ursin G, Parisky YR, Pike MC, Spicer DV (2001) Mammographic density changes during the menstrual cycle. Cancer epidemiology, biomarkers \& prevention : a publication of the American Association for Cancer Research, cosponsored by the American Society of Preventive Oncology 10 (2): 141-142

9. Hovhannisyan G, Chow L, Schlosser A, Yaffe MJ, Boyd NF, Martin LJ (2009) Differences in measured mammographic density in the menstrual cycle. Cancer epidemiology, biomarkers \& prevention : a publication of the American Association for Cancer Research, cosponsored by the American Society of Preventive Oncology 18 (7):1993-1999. doi:10.1158/1055-9965.epi-09-0074 10. Greendale GA, Reboussin BA, Slone S, Wasilauskas C, Pike MC, Ursin G (2003) Postmenopausal hormone therapy and change in mammographic density. Journal of the National Cancer Institute 95 (1):30-37

11. McTiernan A, Martin CF, Peck JD, Aragaki AK, Chlebowski RT, Pisano ED, Wang CY, Brunner RL, Johnson KC, Manson JE, Lewis CE, Kotchen JM, Hulka BS (2005) Estrogen-plus-progestin use and mammographic density in postmenopausal women: Women's Health Initiative randomized trial. Journal of the National Cancer Institute 97 (18):1366-1376. doi:10.1093/jnci/dji279

12. Boyd NF, Melnichouk O, Martin LJ, Hislop G, Chiarelli AM, Yaffe MJ, Minkin S (2011) Mammographic density, response to hormones, and breast cancer risk. Journal of clinical oncology : official journal of the American Society of Clinical Oncology 29 (22):2985-2992. doi:10.1200/jco.2010.33.7964

13. Rossouw JE, Anderson GL, Prentice RL, LaCroix AZ, Kooperberg C, Stefanick ML, Jackson RD, Beresford SA, Howard BV, Johnson KC, Kotchen JM, Ockene J (2002) Risks and benefits of estrogen plus progestin in healthy postmenopausal women: principal results From the Women's Health Initiative randomized controlled trial. JAMA : the journal of the American Medical Association 288 (3):321-333

14. Schoemaker MJ, Folkerd EJ, Jones ME, Rae M, Allen S, Ashworth A, Dowsett M, Swerdlow AJ (2014) Combined effects of endogenous sex hormone levels and mammographic density on postmenopausal breast cancer risk: results from the Breakthrough Generations Study. British journal of cancer 110 (7):1898-1907. doi:10.1038/bjc.2014.64 
15. Key TJ, Appleby PN, Reeves GK, Roddam AW (2010) Insulin-like growth factor 1 (IGF1), IGF binding protein 3 (IGFBP3), and breast cancer risk: pooled individual data analysis of 17 prospective studies. The lancet oncology 11 (6):530-542. doi:10.1016/s1470-2045(10)70095-4

16. Hamelers IH, Steenbergh PH (2003) Interactions between estrogen and insulin-like growth factor signaling pathways in human breast tumor cells. Endocrine-related cancer 10 (2):331-345

17. Kaaks R, Johnson T, Tikk K, Sookthai D, Tjonneland A, Roswall N, Overvad K, Clavel-Chapelon F, Boutron-Ruault MC, Dossus L, Rinaldi S, Romieu I, Boeing H, Schutze M, Trichopoulou A, Lagiou P, Trichopoulos D, Palli D, Grioni S, Tumino R, Sacerdote C, Panico S, Buckland G, Arguelles M, Sanchez MJ, Amiano P, Chirlaque MD, Ardanaz E, Bueno-de-Mesquita HB, van Gils $\mathrm{CH}$, Peeters PH, Andersson A, Sund M, Weiderpass E, Torhild Gram I, Lund E, Khaw KT, Wareham N, Key TJ, Travis RC, Merritt MA, Gunter MJ, Riboli E, Lukanova A (2013) Insulin-like growth factor I and risk of breast cancer by age and hormone receptor status-A prospective study within the EPIC cohort. International journal of cancer Journal international du cancer. doi:10.1002/ijc.28589 18. Felice DL, El-Shennawy L, Zhao S, Lantvit DL, Shen Q, Unterman TG, Swanson SM, Frasor J (2013) Growth hormone potentiates 17beta-estradiol-dependent breast cancer cell proliferation independently of IGF-I receptor signaling. Endocrinology 154 (9):3219-3227. doi:10.1210/en.20122208

19. Furberg AS, Jasienska G, Bjurstam N, Torjesen PA, Emaus A, Lipson SF, Ellison PT, Thune I (2005) Metabolic and hormonal profiles: HDL cholesterol as a plausible biomarker of breast cancer risk. The Norwegian EBBA Study. Cancer epidemiology, biomarkers \& prevention : a publication of the American Association for Cancer Research, cosponsored by the American Society of Preventive Oncology 14 (1):33-40

20. Emaus A, Espetvedt S, Veierod MB, Ballard-Barbash R, Furberg AS, Ellison PT, Jasienska G, Hjartaker A, Thune I (2008) 17-beta-estradiol in relation to age at menarche and adult obesity in premenopausal women. Human reproduction (Oxford, England) 23 (4):919-927.

doi:10.1093/humrep/dem432

21. Emaus A, Veierod MB, Furberg AS, Espetvedt S, Friedenreich C, Ellison PT, Jasienska G, Andersen LB, Thune I (2008) Physical activity, heart rate, metabolic profile, and estradiol in premenopausal women. Medicine and science in sports and exercise 40 (6):1022-1030. doi:10.1249/MSS.0b013e318167411f

22. Finstad SE, Emaus A, Tretli S, Jasienska G, Ellison PT, Furberg AS, Wist EA, Thune I (2009) Adult height, insulin, and 17beta-estradiol in young women. Cancer epidemiology, biomarkers \& prevention : a publication of the American Association for Cancer Research, cosponsored by the American Society of Preventive Oncology 18 (5):1477-1483. doi:10.1158/1055-9965.epi-08-0972 23. Bellem A, Meiyappan S, Romans S, Einstein G (2011) Measuring estrogens and progestagens in humans: an overview of methods. Gender medicine 8 (5):283-299. doi:10.1016/j.genm.2011.07.001 24. Ellison PT (1994) Advances in human reproductive ecology. Annual review of anthropology 23:255-275. doi:10.1146/annurev.an.23.100194.001351

25. Lipson SF, Ellison PT (1989) Development of protocols for the application of salivary steroid analysis to field conditions. American Journal of Human Biology 1 (3):249-255.

doi:10.1002/ajhb.1310010304

26. Ellison PT, Lipson SF (1999) Salivary estradiol--a viable alternative? Fertility and sterility 72 (5):951-952

27. Bjurstam N, Bjorneld L, Warwick J, Sala E, Duffy SW, Nystrom L, Walker N, Cahlin E, Eriksson O, Hafstrom LO, Lingaas H, Mattsson J, Persson S, Rudenstam CM, Salander H, Save-Soderbergh J, Wahlin T (2003) The Gothenburg Breast Screening Trial. Cancer 97 (10):2387-2396. doi:10.1002/cncr.11361

28. Ursin G, Astrahan MA, Salane M, Parisky YR, Pearce JG, Daniels JR, Pike MC, Spicer DV (1998) The detection of changes in mammographic densities. Cancer epidemiology, biomarkers \& prevention : a publication of the American Association for Cancer Research, cosponsored by the American Society of Preventive Oncology 7 (1):43-47

29. Ursin G, Ma H, Wu AH, Bernstein L, Salane M, Parisky YR, Astrahan M, Siozon CC, Pike MC (2003) Mammographic density and breast cancer in three ethnic groups. Cancer epidemiology, biomarkers \& prevention : a publication of the American Association for Cancer Research, cosponsored by the American Society of Preventive Oncology 12 (4):332-338 
30. Matthews JN, Altman DG, Campbell MJ, Royston P (1990) Analysis of serial measurements in medical research. BMJ (Clinical research ed) 300 (6719):230-235

31. Bertrand KA, Eliassen AH, Hankinson SE, Gierach GL, Xu X, Rosner B, Ziegler RG, Tamimi RM (2012) Urinary estrogens and estrogen metabolites and mammographic density in premenopausal women. Breast cancer research and treatment 136 (1):277-287. doi:10.1007/s10549-012-2240-0 32. Maskarinec G, Heak S, Morimoto Y, Custer L, Franke AA (2012) The relation of urinary estrogen metabolites with mammographic densities in premenopausal women. Cancer epidemiology 36 (5):e310-316. doi:10.1016/j.canep.2012.03.014

33. Walker K, Fletcher O, Johnson N, Coupland B, McCormack VA, Folkerd E, Gibson L, Hillier SG, Holly JM, Moss S, Dowsett M, Peto J, dos Santos Silva I (2009) Premenopausal mammographic density in relation to cyclic variations in endogenous sex hormone levels, prolactin, and insulin-like growth factors. Cancer research 69 (16):6490-6499. doi:10.1158/0008-5472.can-09-0280

34. Maskarinec G, Takata Y, Chen Z, Gram IT, Nagata C, Pagano I, Hayashi K, Arendell L, Skeie G, Rinaldi S, Kaaks R (2007) IGF-I and mammographic density in four geographic locations: a pooled analysis. International journal of cancer Journal international du cancer 121 (8):1786-1792.

doi:10.1002/ijc.22834

35. dos Santos Silva I, Johnson N, De Stavola B, Torres-Mejia G, Fletcher O, Allen DS, Allen NE, Key TJ, Fentiman IS, Holly JM, Peto J (2006) The insulin-like growth factor system and mammographic features in premenopausal and postmenopausal women. Cancer epidemiology, biomarkers \& prevention : a publication of the American Association for Cancer Research, cosponsored by the American Society of Preventive Oncology 15 (3):449-455. doi:10.1158/10559965.epi-05-0555

36. Rinaldi S, Biessy C, Hernandez M, Lesueur F, dos-Santos-Silva I, Rice MS, Lajous M, LopezRidaura R, Torres-Mejia G, Romieu I (2014) Circulating concentrations of insulin-like growth factorI, insulin-like growth factor-binding protein-3, genetic polymorphisms and mammographic density in premenopausal Mexican women: results from the ESMaestras cohort. International journal of cancer Journal international du cancer 134 (6):1436-1444. doi:10.1002/ijc.28469

37. van Gils CH, Hendriks JH, Otten JD, Holland R, Verbeek AL (2000) Parity and mammographic breast density in relation to breast cancer risk: indication of interaction. European journal of cancer prevention : the official journal of the European Cancer Prevention Organisation (ECP) 9 (2):105-111 38. Boyd NF, Martin LJ, Yaffe MJ, Minkin S (2011) Mammographic density and breast cancer risk: current understanding and future prospects. Breast cancer research : BCR 13 (6):223. doi: $10.1186 /$ bcr2942

39. Martin LJ, Boyd NF (2008) Mammographic density. Potential mechanisms of breast cancer risk associated with mammographic density: hypotheses based on epidemiological evidence. Breast cancer research : BCR 10 (1):201. doi:10.1186/bcr1831

40. Lokate M, Peeters PH, Peelen LM, Haars G, Veldhuis WB, van Gils CH (2011) Mammographic density and breast cancer risk: the role of the fat surrounding the fibroglandular tissue. Breast cancer research : BCR 13 (5):R103. doi:10.1186/bcr3044

41. Yu Z, Gao W, Jiang E, Lu F, Zhang L, Shi Z, Wang X, Chen L, Lv T (2013) Interaction between IGF-IR and ER induced by E2 and IGF-I. PloS one 8 (5):e62642. doi:10.1371/journal.pone.0062642

42. Werner H (2012) Tumor suppressors govern insulin-like growth factor signaling pathways: implications in metabolism and cancer. Oncogene 31 (22):2703-2714. doi:10.1038/onc.2011.447 43. Boyd NF, Stone J, Martin LJ, Jong R, Fishell E, Yaffe M, Hammond G, Minkin S (2002) The association of breast mitogens with mammographic densities. British journal of cancer 87 (8):876-882. doi:10.1038/sj.bjc. 6600537

44. Meggiorini ML, Cipolla V, Borgoni G, Nofroni I, Pala A, de Felice C (2012) Possible effects of insulin-like growth factor-I, IGF-binding protein-3 and IGF-1/IGFBP-3 molar ratio on mammographic density: a cross-sectional study. European journal of gynaecological oncology 33 (1):74-78

45. McCormack VA, Dowsett M, Folkerd E, Johnson N, Palles C, Coupland B, Holly JM,

Vinnicombe SJ, Perry NM, dos Santos Silva I (2009) Sex steroids, growth factors and mammographic density: a cross-sectional study of UK postmenopausal Caucasian and Afro-Caribbean women. Breast cancer research : BCR 11 (3):R38. doi:10.1186/bcr2325

46. Borugian MJ, Spinelli JJ, Gordon PB, Abanto Z, Brooks-Wilson A, Pollak MN, Warren LJ, Hislop TG, Gallagher RP (2014) Fasting insulin and endogenous hormones in relation to premenopausal 
breast density (Canada). Cancer causes \& control : CCC 25 (3):385-394. doi:10.1007/s10552-0140339-9

47. Harrela M, Koistinen H, Kaprio J, Lehtovirta M, Tuomilehto J, Eriksson J, Toivanen L, Koskenvuo M, Leinonen P, Koistinen R, Seppala M (1996) Genetic and environmental components of interindividual variation in circulating levels of IGF-I, IGF-II, IGFBP-1, and IGFBP-3. The Journal of clinical investigation 98 (11):2612-2615. doi:10.1172/jci119081

48. Ruan W, Kleinberg DL (1999) Insulin-like growth factor I is essential for terminal end bud formation and ductal morphogenesis during mammary development. Endocrinology 140 (11):50755081. doi:10.1210/endo.140.11.7095

49. Kleinberg DL, Barcellos-Hoff MH (2011) The pivotal role of insulin-like growth factor I in normal mammary development. Endocrinology and metabolism clinics of North America 40 (3):461471, vii. doi:10.1016/j.ecl.2011.06.001

50. Kleinberg DL, Ruan W (2008) IGF-I, GH, and sex steroid effects in normal mammary gland development. Journal of mammary gland biology and neoplasia 13 (4):353-360. doi:10.1007/s10911008-9103-7

51. Saftlas AF, Hoover RN, Brinton LA, Szklo M, Olson DR, Salane M, Wolfe JN (1991)

Mammographic densities and risk of breast cancer. Cancer 67 (11):2833-2838

52. Diorio C, Brisson J, Berube S, Pollak M (2008) Intact and total insulin-like growth factor-binding protein-3 (IGFBP-3) levels in relation to breast cancer risk factors: a cross-sectional study. Breast cancer research : BCR 10 (3):R42. doi:10.1186/bcr2093

53. Borofsky ND, Vogelman JH, Krajcik RA, Orentreich N (2002) Utility of insulin-like growth factor-1 as a biomarker in epidemiologic studies. Clinical chemistry 48 (12):2248-2251

54. Gann PH, Giovanazzi S, Van Horn L, Branning A, Chatterton RT, Jr. (2001) Saliva as a medium for investigating intra- and interindividual differences in sex hormone levels in premenopausal women. Cancer epidemiology, biomarkers \& prevention : a publication of the American Association for Cancer Research, cosponsored by the American Society of Preventive Oncology 10 (1):59-64 55. Morrow M, Chatterton RT, Jr., Rademaker AW, Hou N, Jordan VC, Hendrick RE, Khan SA (2010) A prospective study of variability in mammographic density during the menstrual cycle. Breast cancer research and treatment 121 (3):565-574. doi:10.1007/s10549-009-0496-9

56. Boyd NF, Martin LJ, Sun L, Guo H, Chiarelli A, Hislop G, Yaffe M, Minkin S (2006) Body size, mammographic density, and breast cancer risk. Cancer epidemiology, biomarkers \& prevention : a publication of the American Association for Cancer Research, cosponsored by the American Society of Preventive Oncology 15 (11):2086-2092. doi:10.1158/1055-9965.epi-06-0345

57. Byrne C, Schairer C, Wolfe J, Parekh N, Salane M, Brinton LA, Hoover R, Haile R (1995)

Mammographic features and breast cancer risk: effects with time, age, and menopause status. Journal of the National Cancer Institute 87 (21):1622-1629 
Table 1 Characteristics of the study population by median split of percent and absolute mammographic density: The Norwegian Energy Balance and Breast cancer Aspects (EBBA)I study $(\mathrm{n}=202)^{\mathrm{a}}$

\begin{tabular}{|c|c|c|c|c|c|c|}
\hline \multirow[b]{3}{*}{ Characteristics } & \multicolumn{2}{|c|}{$\begin{array}{c}\text { Percent mammographic } \\
\text { density }^{\mathrm{e}}(\%)\end{array}$} & \multicolumn{4}{|c|}{$\begin{array}{c}\text { Absolute mammographic } \\
\text { density }^{\mathrm{e}}\left(\mathrm{cm}^{2}\right)\end{array}$} \\
\hline & $\begin{array}{c}\leq 28.5 \\
(n=101)^{a}\end{array}$ & $\begin{array}{c}>28.5 \\
(n=101)^{a}\end{array}$ & & $\begin{array}{l}\leq 32.4 \\
(n=101)^{a}\end{array}$ & $\begin{array}{c}>32.4 \\
(n=101)^{a}\end{array}$ & \\
\hline & Mean (SD) & Mean (SD) & $\begin{array}{c}p \text { - } \\
\text { value }\end{array}$ & Mean (SD) & Mean (SD) & $\begin{array}{c}p \text { - } \\
\text { value }\end{array}$ \\
\hline Age (years) & $31.54(2.72)$ & $29.88(3.18)$ & $<0.001$ & $31.48(2.80)$ & $29.94(3.14)$ & $<0.001$ \\
\hline Education (total years) & $16.14(3.20)$ & $16.01(2.88)$ & 0.771 & $15.92(2.99)$ & $16.23(3.09)$ & 0.467 \\
\hline \multicolumn{7}{|l|}{ Body composition $^{\text {b }}$} \\
\hline $\operatorname{BMI}\left(\mathrm{kg} / \mathrm{m}^{2}\right)$ & $26.15(3.90)$ & $22.66(2.73)$ & $<0.001$ & $25.42(4.07)$ & $23.39(3.19)$ & $<0.001$ \\
\hline Waist circumference $(\mathrm{cm})$ & $84.43(9.92)$ & $74.83(6.93)$ & $<0.001$ & $82.45(10.35)$ & $76.81(8.35)$ & $<0.001$ \\
\hline $\begin{array}{l}\text { Tissue fat, DEXA scan } \\
(\%)^{\mathrm{e}} \\
\text { Reproductive factors }\end{array}$ & $37.95(6.72)$ & $30.54(6.55)$ & $<0.001$ & $36.39(7.50)$ & $32.10(7.10)$ & $<0.001$ \\
\hline Parity (no children) & $1.35(1.21)$ & $0.49(0.84)$ & $<0.001$ & $1.25(1.14)$ & $0.58(1.02)$ & $<0.001$ \\
\hline Age at menarche (years) & $12.87(1.31)$ & $13.35(1.40)$ & 0.011 & $12.91(1.34)$ & $13.31(1.39)$ & 0.038 \\
\hline Cycle length (days) & $27.87(3.00)$ & $28.67(3.22)$ & 0.069 & $27.78(3.10)$ & $28.76(3.10)$ & 0.026 \\
\hline \multicolumn{7}{|l|}{ Serum concentrations ${ }^{c}$} \\
\hline Glucose (mmol/l) & $5.15(0.59)$ & $4.90(0.51)$ & 0.002 & $5.10(0.62)$ & $4.95(0.49)$ & 0.049 \\
\hline Insulin (pmol/1) & $90.42(61.26)$ & $80.96(57.60)$ & 0.260 & $91.06(68.26)$ & $80.32(48.97)$ & 0.200 \\
\hline IGF-1 (nmol/1) & $24.66(6.27)$ & $25.36(6.41)$ & 0.439 & $24.23(6.00)$ & $25.79(6.59)$ & 0.079 \\
\hline IGFBP-3 (nmol/1) & $100.51(15.93)$ & $100.38(14.17)$ & 0.951 & $98.63(15.17)$ & $102.27(14.75)$ & 0.085 \\
\hline Growth hormone (mlU/l) & $3.03(4.90)$ & $4.21(7.02)$ & 0.175 & $3.13(5.19)$ & $4.11(6.85)$ & 0.260 \\
\hline \multicolumn{7}{|l|}{ Serum hormones $^{c}$} \\
\hline \multicolumn{7}{|l|}{ Salivary hormones $^{\mathrm{d}}$} \\
\hline $\begin{array}{l}\text { Overall average } 17 \beta \text {-estradiol } \\
\text { (pmol/l) } \\
\text { Lifestyle factors }\end{array}$ & $17.55(8.78)$ & $18.50(8.73)$ & 0.441 & $17.63(8.42)$ & $18.43(9.09)$ & 0.515 \\
\hline Energy intake (kJ/day) & $7.94(1.94)$ & $8.27(1.85)$ & 0.218 & $7.89(1.93)$ & $8.32(1.85)$ & 0.106 \\
\hline Previous use of OC (\%) & $1.16(0.37)$ & $1.18(0.39)$ & 0.708 & $1.18(0.39)$ & $1.16(0.37)$ & 0.708 \\
\hline $\begin{array}{l}\text { Leisure time (MET } \\
\text { hours/week) }\end{array}$ & $62.49(121.61)$ & $53.03(37.64)$ & 0.456 & $59.99(121.14)$ & $55.50(39.55)$ & 0.724 \\
\hline Alcohol (units/week) & $2.56(3.10)$ & $3.24(3.61)$ & 0.154 & $2.50(3.13)$ & $3.30(3.57)$ & 0.091 \\
\hline Current smokers (\%) & $1.76(0.43)$ & $1.78(0.42)$ & 0.710 & $1.77(0.42)$ & $1.77(0.42)$ & 0.970 \\
\hline
\end{tabular}

NOTE: All analyses have used Students t-test

BMI, body mass index; DEXA, dual-energy X-ray; IGF-1, insulin-like growth factor-1; IGFBP-3, insulin-like growth factor binding protein-3; OC, oral contraceptives; MET, metabolic equivalents; SD, standard deviations.

${ }^{\mathrm{a} N u m b e r s ~ m a y ~ v a r y ~ d u e ~ t o ~ m i s s i n g ~ i n f o r m a t i o n . ~}$

${ }^{\mathrm{b}}$ Measurements at days 1-5 after onset of menstrual cycle.

${ }^{\mathrm{c}}$ Serum samples in early follicular phase: days 1-5 after onset of menstrual cycle.

${ }^{\mathrm{d}}$ Daily saliva samples throughout an entire menstrual cycle.

${ }^{\mathrm{e}}$ Mammograms and total tissue fat (DEXA) were taken days 7-12 (mid-cycle phase). 
Table 2 Odds ratios (ORs) with $95 \%$ Confidence interval (CI) for higher percent mammographic density $(>28.5 \%)$ by estrogen among premenopausal women, stratified by median split of insulin-like growth factor (IGF)-1.

\begin{tabular}{|c|c|c|c|c|c|}
\hline \multirow[b]{3}{*}{ Hormones } & \multicolumn{5}{|c|}{ IGF-1 } \\
\hline & \multicolumn{2}{|c|}{$\leq 25 \mathrm{nmol} / / \mathrm{n}=105^{\mathrm{a}}$} & \multicolumn{2}{|c|}{$>25 \mathrm{nmol} / \mathrm{ln}=99^{\mathrm{a}}$} & \multirow{2}{*}{$\begin{array}{c}\text { Interaction } \\
p \text {-value }\end{array}$} \\
\hline & OR & $95 \%$ CI & OR & $95 \%$ CI & \\
\hline \multicolumn{6}{|l|}{ Serum 17ß-estradiol (pmol/l) } \\
\hline \multicolumn{6}{|l|}{ Early follicular ${ }^{\mathrm{b}}$} \\
\hline$\leq 130.0$ & 1.00 & (Referent) & 1.00 & (Referent) & \\
\hline$>130.0$ & 1.15 & $(0.43-3.12)$ & 1.57 & $(0.56-4.43)$ & 0.776 \\
\hline Estradiol per $1 \mathrm{SD}(61.59 \mathrm{pmol} / \mathrm{l})$ & 0.84 & $(0.47-1.52)$ & 1.22 & $(0.77-1.95)$ & 0.461 \\
\hline \multicolumn{6}{|l|}{ Salivary $17 \beta$-estradiol (pmol/l) } \\
\hline \multicolumn{6}{|l|}{ Overall $^{\mathrm{c}}$} \\
\hline$\leq 16.8$ & 1.00 & (Referent) & 1.00 & (Referent) & \\
\hline$>16.8$ & 1.21 & $(0.42-3.46)$ & 4.13 & $(1.33-12.83)$ & 0.056 \\
\hline Estradiol per $1 \mathrm{SD}(8.79 \mathrm{pmol} / \mathrm{l})$ & 1.52 & $(0.81-2.82)$ & 1.81 & $(1.08-3.03)$ & 0.356 \\
\hline \multicolumn{6}{|l|}{ Mid-menstrual $^{\mathrm{c}}$} \\
\hline$\leq 16.9$ & 1.00 & (Referent) & 1.00 & (Referent) & \\
\hline$>16.9$ & 1.10 & $(0.35-3.44)$ & 4.35 & $(1.42-13.35)$ & 0.028 \\
\hline Estradiol per $1 \mathrm{SD}(8.98 \mathrm{pmol} / \mathrm{l})$ & 1.38 & $(0.67-2.86)$ & 1.80 & $(1.09-2.97)$ & 0.183 \\
\hline \multicolumn{6}{|l|}{ Follicular ${ }^{\mathrm{e}}$} \\
\hline$\leq 17.5$ & 1.00 & (Referent) & 1.00 & (Referent) & \\
\hline$>17.5$ & 1.35 & $(0.44-4.16)$ & 3.84 & $(1.20-12.26)$ & 0.057 \\
\hline Estradiol per $1 \mathrm{SD}(9.58 \mathrm{pmol} / \mathrm{l})$ & 1.39 & $(0.69-2.80)$ & 1.99 & $(1.14-3.48)$ & 0.101 \\
\hline \multicolumn{6}{|l|}{ Luteal $^{\mathrm{f}}$} \\
\hline$\leq 15.5$ & 1.00 & (Referent) & 1.00 & (Referent) & \\
\hline$>15.5$ & 1.91 & $(0.61-6.00)$ & 5.26 & $(1.67-16.56)$ & 0.071 \\
\hline Estradiol per $1 \mathrm{SD}(9.22 \mathrm{pmol} / \mathrm{l})$ & 1.28 & $(0.64-2.57)$ & 1.62 & $(1.02-2.58)$ & 0.282 \\
\hline \multicolumn{6}{|l|}{$\mathrm{AUC}^{\mathrm{g}}(\mathrm{pmol} / 1 \mathrm{x}$ cycle $)$} \\
\hline$\leq 251.25$ & 1.00 & (Referent) & 1.00 & (Referent) & \\
\hline$>251.25$ & 1.25 & $(0.40-3.90)$ & 4.35 & $(1.42-13.35)$ & 0.038 \\
\hline AUC per $1 \mathrm{SD}$ (133.01 pmol/1 x cycle) & 1.38 & $(0.67-2.86)$ & 1.81 & $(1.10-3.01)$ & 0.176 \\
\hline
\end{tabular}

NOTE: All analyses have used multivariable logistic regression models, and are adjusted for age (continuous), body mass index (continuous), number of children (continuous), and IGFBP-3 (continuous).

AUC, area under curve; CI, confidence interval; IGF-1, insulin-like growth factor-1; IGFBP-3, insulin-like growth factor binding protein-3; OR, odds ratio; SD, standard deviation.

${ }^{a}$ Numbers may vary due to missing information.

${ }^{\mathrm{b}}$ Serum samples in early follicular phase: days 1-5 after onset of menstrual cycle.

${ }^{c}$ Daily saliva samples throughout an entire menstrual cycle.

${ }^{\mathrm{d}}$ Daily saliva samples in mid-menstrual phase: aligned cycle days $-7,+6$

${ }^{\mathrm{e}}$ Daily saliva samples in follicular phase: aligned cycle days $-7,-1$.

${ }^{\mathrm{f}}$ Daily saliva samples in luteal phase: aligned cycle days $0,+6$

${ }^{\mathrm{g}} \mathrm{AUC}$ estimated from aligned cycle days $-10,+9$ 
Table 3 Odds ratios (ORs) with $95 \%$ Confidence interval (CI) for higher percent mammographic density ( $>28.5 \%)$ by estrogen among premenopausal women, stratified by median split of growth hormone $(\mathrm{GH})$.

\begin{tabular}{|c|c|c|c|c|c|}
\hline \multirow[b]{3}{*}{ Hormones } & \multicolumn{4}{|c|}{ GH } & \multirow{3}{*}{$\begin{array}{c}\text { Interaction } \\
p \text {-value }\end{array}$} \\
\hline & \multicolumn{2}{|c|}{$\leq 0.80 \mathrm{mlU} / \mathrm{l} \mathrm{n}=102^{\mathrm{a}}$} & \multicolumn{2}{|c|}{$>0.80 \mathrm{mlU} / \mathrm{l} \mathrm{n}=93^{\mathrm{a}}$} & \\
\hline & OR & $95 \% \mathrm{CI}$ & OR & $95 \% \mathrm{CI}$ & \\
\hline \multicolumn{6}{|l|}{ Serum $17 \beta$-estradiol (pmol/l) } \\
\hline \multicolumn{6}{|l|}{ Early follicular ${ }^{\mathrm{b}}$} \\
\hline$\leq 130.0$ & 1.00 & (Referent) & 1.00 & (Referent) & \\
\hline$>130.0$ & 1.00 & $(0.35-2.78)$ & 2.27 & $(0.76-6.73)$ & 0.321 \\
\hline Estradiol per $1 \mathrm{SD}(61.59 \mathrm{pmol} / \mathrm{l})$ & 1.08 & $(0.59-1.98)$ & 1.02 & $(0.63-1.63)$ & 0.743 \\
\hline \multicolumn{6}{|l|}{ Salivary $17 \beta$-estradiol (pmol/l) } \\
\hline \multicolumn{6}{|l|}{ Overall $^{\mathrm{c}}$} \\
\hline$\leq 16.8$ & 1.00 & (Referent) & 1.00 & (Referent) & \\
\hline$>16.8$ & 0.88 & $(0.30-2.61)$ & 4.17 & $(1.41-12.28)$ & 0.024 \\
\hline Estradiol per $1 \mathrm{SD}(8.79 \mathrm{pmol} / \mathrm{l})$ & 1.57 & $(0.91-2.69)$ & 2.08 & $(1.10-3.94)$ & 0.256 \\
\hline \multicolumn{6}{|l|}{ Mid-menstrual $^{\mathrm{d}}$} \\
\hline$\leq 16.9$ & 1.00 & (Referent) & 1.00 & (Referent) & \\
\hline$>16.9$ & 1.16 & $(0.37-3.59)$ & 3.05 & $(1.02-9.12)$ & 0.170 \\
\hline Estradiol per $1 \mathrm{SD}(8.98 \mathrm{pmol} / \mathrm{l})$ & 1.56 & $(0.89-2.75)$ & 2.06 & $(1.06-4.00)$ & 0.328 \\
\hline \multicolumn{6}{|l|}{ Follicular $^{\mathrm{e}}$} \\
\hline$\leq 17.5$ & 1.00 & (Referent) & 1.00 & (Referent) & \\
\hline$>17.5$ & 1.19 & $(0.38-3.73)$ & 4.09 & $(1.27-13.12)$ & 0.083 \\
\hline Estradiol per $1 \mathrm{SD}(9.58 \mathrm{pmol} / \mathrm{l})$ & 1.40 & $(0.83-2.37)$ & 2.78 & $(1.29-6.03)$ & 0.063 \\
\hline \multicolumn{6}{|l|}{ Luteal $^{\mathrm{f}}$} \\
\hline$\leq 15.5$ & 1.00 & (Referent) & 1.00 & (Referent) & \\
\hline$>15.5$ & 2.34 & $(0.71-7.77)$ & 3.70 & $(1.25-10.96)$ & 0.361 \\
\hline Estradiol per $1 \mathrm{SD}(9.22 \mathrm{pmol} / \mathrm{l})$ & 1.69 & $(0.94-3.03)$ & 1.58 & $(0.88-2.84)$ & 0.949 \\
\hline \multicolumn{6}{|l|}{$\mathrm{AUC}^{\mathrm{g}}(\mathrm{pmol} / \mathrm{x}$ cycle $)$} \\
\hline$\leq 251.25$ & 1.00 & (Referent) & 1.00 & (Referent) & \\
\hline$>251.25$ & 1.33 & $(0.43-4.12)$ & 3.05 & $(1.02-9.12)$ & 0.586 \\
\hline AUC per $1 \mathrm{SD}$ (133.01 pmol/1 x cycle) & 1.60 & $(0.91-2.83)$ & 2.06 & $(1.05-4.04)$ & 0.348 \\
\hline
\end{tabular}

NOTE: All analyses have used multivariable logistic regression models, and are adjusted for age (continuous), body mass index (continuous), and number of children (continuous).

AUC, area under curve; CI, confidence interval; GH, growth hormone; OR, odds ratio; SD, standard deviation.

${ }^{a}$ Numbers may vary due to missing information.

${ }^{\mathrm{b}}$ Serum samples in early follicular phase: days 1-5 after onset of menstrual cycle.

${ }^{\mathrm{c}}$ Daily saliva samples throughout an entire menstrual cycle.

${ }^{\mathrm{d}}$ Daily saliva samples in mid-menstrual phase: aligned cycle days $-7,+6$

${ }^{\mathrm{e}}$ Daily saliva samples in follicular phase: aligned cycle days $-7,-1$.

${ }^{\mathrm{f}}$ Daily saliva samples in luteal phase: aligned cycle days $0,+6$

${ }^{\mathrm{g}}$ AUC estimated from aligned cycle days $-10,+9$ 